\title{
Malignant middle cerebral artery infarction
}

\author{
Osama S M Amin
}

Department of Medicine, International Medical University School of Medicine, Negeri Sembilan, Malaysia

\section{Correspondence to} Dr Osama SM Amin, dr.osama.amin@gmail.com

Accepted 28 March 2017

\section{DESCRIPTION}

A 55-year-old man with hypertension was referred from a rural hospital. Two days before, he had developed a cardioembolic ischaemic stroke, which resulted in left-sided hemiparesis and hemianaesthesia. On the day of referral, he developed repeated vomiting and severe headache, followed by progressive obtundation and coma. There was papilloedema. Both planter reflexes were extensors. A non-contrast CT brain scan was done (figure 1). The initial CT brain scan was not available for comparison. The patient was outside the international guidelines on timing of decompressive hemicraniectomy (DCH) for ischaemic stroke and was extremely unwell. After a few hours, he died from 'malignant middle cerebral artery (MCA) infarction'.

Embolic occlusion of the proximal main stem of the MCA results in ischaemic damage of the entire region supplied by that artery. This large core of ischaemia occupies most of the hemisphere and is surrounded by a relatively small penumbra. Cytotoxic oedema ensues rapidly which further disrupts the blood-brain barrier and culminates in vasogenic oedema. The end result is a huge space-occupying mass, which

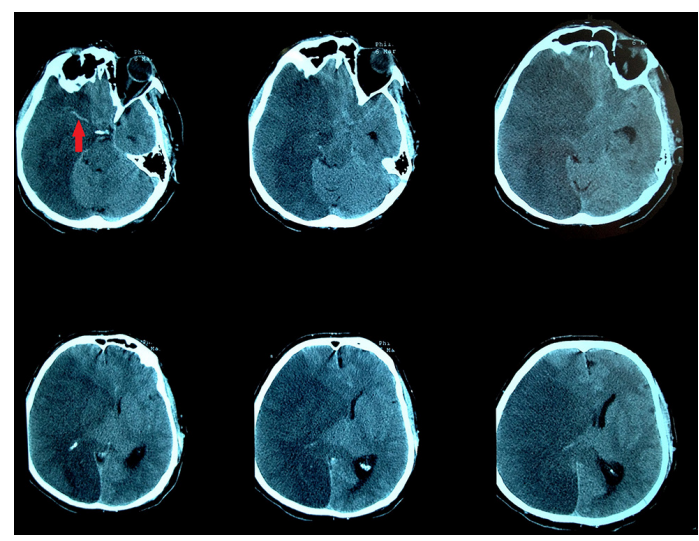

Figure 1 Axial non-contrast $\mathrm{CT}$ brain scan of the patient 2 days after developing right-sided middle cerebral artery embolic occlusion. Note that almost the entire right cerebral hemisphere is swollen and has compressed the left hemisphere. The midline structures were displaced to the left; the compressed frontal horn of the right lateral ventricle lies entirely within the left side. The right putamen and caudate have moved and rest within the midline. The left upper $\mathrm{CT}$ image section shows a prominent linear hyperdensity within the infarcted area; this is the embolus within the right middle cerebral artery, the so-called hyperdense middle cerebral artery sign (red arrow).

\section{Learning points}

- Malignant middle cerebral artery (MCA) infarction should always be anticipated in patients who demonstrate more than $50 \%$ infarction of the MCA region. The large ischaemic and oedematous brain tissue acts a massive space-occupying lesion.

- The neurosurgical department should be consulted within 48 hours of stroke onset. The development of severe headache, vomiting, progressive impairment in consciousness and papilloedema should prompt the physician to think of a malignant course and manage the patient vigilantly.

- Decompressive hemicraniectomy, if done within 48 hours of onset of symptoms, can reduce the mortality and morbidity figures. In general, patients should not be excluded from this form of intervention based on age alone because this is a controversial matter.

compresses the contralateral hemisphere and displaces the midline structures. Transtentorial herniation, brainstem compression and death are the terminal events. ${ }^{1}$ This syndrome, which is a rare neurovascular condition that occurs in $2.3 \%$ of ischaemic strokes in the MCA, ${ }^{2}$ confers an $80 \%$ mortality rate in conservatively treated patients. If DCH (usually at least $12 \mathrm{~cm}$ in size) is carried out within 48 hours of onset of symptoms, it can reduce mortality and morbidity 6 and 12 months poststroke. DCH increased survival without severe disability among patients aged 61 years or older with a malignant MCA infarction.

Contributors OSMA managed the patient, took the images and drafted the paper.

Competing interests None declared.

Patient consent Obtained.

Provenance and peer review Not commissioned; externally peer reviewed.

(c) BMJ Publishing Group Ltd (unless otherwise stated in the text of the article) 2017. All rights reserved. No commercial use is permitted unless otherwise expressly granted.

\section{REFERENCES}

1 Treadwell SD, Thanvi B. Malignant middle cerebral artery (MCA) infarction: pathophysiology, diagnosis and management. Postgrad Med J 2010:86:235-42.

2 Arboix A, García-Eroles L, Oliveres M, et al. Malignant middle cerebral artery infarction: a clinical study of 32 patients. Rev Invest Clin 2015;67:64-70.

3 Jüttler E, Bösel J, Amiri H, et al. DESTINY II: decompressive surgery for the treatment of malignant INfarction of the middle cerebral arterY II. Int J Stroke 2011;6:79-86. 
Images in...

Copyright 2017 BMJ Publishing Group. All rights reserved. For permission to reuse any of this content visit http://group.bmj.com/group/rights-licensing/permissions.

BMJ Case Report Fellows may re-use this article for personal use and teaching without any further permission.

Become a Fellow of BMJ Case Reports today and you can:

- Submit as many cases as you like

- Enjoy fast sympathetic peer review and rapid publication of accepted articles

Access all the published articles

- Re-use any of the published material for personal use and teaching without further permission

For information on Institutional Fellowships contact consortiasales@bmjgroup.com

Visit casereports.bmj.com for more articles like this and to become a Fellow 